\title{
Globalisation and Exploitation in Peru: Strategic Selectivities and the Defeat of Labour in the US-Peru Trade Promotion Agreement
}

\author{
Bart-Jaap Verbeek, Radboud University, Nijmegen, The Netherlands
}

\begin{abstract}
This article examines the socio-economic implications of the US-Peru Trade Promotion Agreement for the governance of Peruvian labour relations. It is argued that the trade agreement aims to lock-in the neoliberal market reforms carried out since the 1990s, which have given rise to an exportoriented regime of accumulation that is characterised by considerable labour exploitation. The marginal role of organised labour and social movements to influence the course of events is placed against the backdrop of neoliberal hegemony and the altered state-society relations that followed from it. Most notably, it identifies the incapability of movement leaders to supersede the grassroots level and develop the necessary political linkages on the one hand, and deliberate government strategies that formed part of a powerful pro-free trade coalition of state officials and the corporate sector on the other hand. The article concludes that the ascendency of the neoliberal state has come to rely on increasingly coercive methods to curb more critical and anti-free trade elements in Peruvian organised labour and social movements.
\end{abstract}

\section{KEYWORDS}

Internationalisation of the state, Labour, neoliberalism, Peru, strategic selectivities, Trade Promotion Agreement.

\section{Introduction}

On 1 February 2009, at the height of the global financial and economic crisis, the bilateral free trade agreement between the United States and Peru, also known by its official name Trade Promotion Agreement (TPA), came into force. The upsurge in export-oriented production in primary sectors, fuelled by the prolonged boom in global commodity prices, mobilised an extraordinary thrust in favour of the TPA within the Peruvian political economy, aptly encapsulated by president Toledo's infamous public statement to conclude the agreement 'si o sí, if necessary, at any cost (Perú21, 2005). At the same time, the booming export sectors of Peru's political economy have attracted vast volumes of foreign and domestic investments, leading to newfound processes of commodification and dispossession. This has been accompanied by recurring exploitation of labour 
and environmental destructions, which exacerbate the further impoverishment of urban and rural workers. Labour in the export-oriented production sectors has been characterised by low wages, considerable job insecurity, overtime and low levels of unionisation. Following a decade of neoliberal restructuring, the TPA, hence, constitutes a crucial vehicle in the new Peruvian regime of accumulation to 'lock-in' the neoliberal market reforms conducive to profitable capital accumulation and surplus extraction.

The particular trajectory of trade negotiations with the US has caused a series of integration problems in the Andean countries. Though originally intended as an extension of pre-existing trade preferences granted by the US government to Colombia, Ecuador, Peru and Bolivia under the Andean Trade Promotion and Drug Eradication Act of 2002, Bolivia and Ecuador remained reluctant to go along with the aggressive agenda for trade and investment liberalisation promoted by the US, Colombia and Peru, however, declared themselves eager to continue negotiations on a bilateral basis. While the ratification of the US-Colombia TPA by the US Congress impeded until October 2011, Peru remained the only Andean country that concluded, ratified and implemented the TPA within relative short notice. These ruptures exposed the distinctive and competing development models existing within the Andean region (Latimer, 2012: 80; Higginbottom, 2013: 185). Whereas the governments of Bolivia, Venezuela and Ecuador have been pursuing alternative development models with input and pressures from organised labour and social movements, the governments of Peru and Colombia remained oriented towards free-market policies and continued integration into global circuits of capital accumulation.

The article aims to examine the labour dimension of the TPA by embedding it into the wider transformation of Peru's political economy, which originates in the economic crisis at the end of the 1980s. This transformation has involved a fundamental restructuring of state-society relations marked by the resurgence of the ideology and practice of free market economics, culminating in a neoliberal state project. In the context of a range of neoliberal market reforms, subsequent Peruvian governments have increasingly enacted policies of privatisation, liberalisation and free trade, while, simultaneously, fundamental labour rights have been increasingly curtailed. By focusing on the structural weaknesses of organised labour and other subordinated groups as well as prevailing fractions of Peru's national capitalist class, the article explains how dominant discourses and interests, reflecting an underlying balance of power among social forces and the institutional setting, have influenced the course of events in Peru's trajectory towards the conclusion and implementation of the TPA.

The paper proceeds as follows. The first section offers a theoretical perspective for analysing state power and processes of internationalisation of the state. The second and third sections spell out the socio-economic content of the TPA's labour chapter and the broader implications for labour. It is assessed how organised labour and social movements have been incapable to influence the course of events, while an emergent pro-TPA coalition spread among Peru's capitalist class and state institutions has been successful in curbing anti-TPA sentiments within Peruvian society. The fourth section explains the structural weakness of trade unions and social movements by examining the broader transformation of Peruvian state-society relations, culminating into the neoliberal state project. The fifth section addresses how this transformation has shaped Peru's political economy into an export-oriented regime of accumulation, which is increasingly characterised by high levels of labour exploitation. As the political process through which these market reforms have been materialised has an increasingly disciplinary character, the last section concludes that the neoliberal 
state project has come to rely more and more on coercive methods in which political dissent has become more isolated and criminalised while foreign investors and trading companies continue to generate high profits.

\section{Labour and the Internationalised State}

Labour movements, globally, have been confronted with major challenges in the wake of increasing transnationalisation of production and finance and the concomitant neoliberal restructuring. Flexibilisation, declining unionisation and outright repression of workers in the Global South have been the bitter by-product of the global efforts to open up new markets for exports and investments that enhance the competitiveness of transnationally operating capitalists through enforcing neoliberal instruments of development (cf. Bieler, 2013). The declining capacity of trade unions in developing countries to improve their bargaining position has to be understood against the backdrop of the global transformation of social power relations as well as processes of internationalisation of the state. In particular, the financial and economic crisis has revealed the structural vulnerability of labour vis-à-vis transnational capital, which has been further exacerbated by deliberate state strategies. This section draws on critical IPE perspectives and provides a theoretical outline of the complex interplay of international conditions, institutional developments and social forces that results in the emergence of historically specific social structures of accumulation in the Peruvian context.

In contrast to state-centric approaches that reify states as unitary actors, the state and state power are perceived here as part of a broader ensemble of social relations (Gramsci, 1971). Social forces are shaped, but not determined, by the contradictions and exploitative character of global capitalism and find their bases in the social relations of production (Cox, 1981). An antagonistic relationship between capital and labour emerges out of the structural inequalities in the production process, although engendered by social, political, economic and cultural factors so that different fractions and strata emerge within these classes (Joseph, 2006: 53; Van Apeldoorn, 2002). The fundamental unequal social relations of production are obfuscated by the seemingly voluntary character of market relations of exchange, which mediates the appropriation of surplus through the process of capital circulation (Wood, 2005: 10-11). However, the formation of historically specific social structures should not only be understood as a mere product of structural social inequalities, but also as the result of the strategic action of key societal actors (Van Apeldoorn, 2002). As put by Horn, it is through concrete, and historically specific agency expressed in the construction, articulation and contestation of hegemony in a Gramscian sense that social struggle and processes become manifest' (2012: 580). Indeed, Gramsci depicts power not only as an underpinning of coercion, but emphasises also the importance of consent to reach hegemony. This consensual feature of power influences the prevalence of hegemony, albeit, coercion is always latently present (Cox, 1983: 164).

Capitalists continue to depend on the coercive functions of the state to secure the social order of private property relations and to maintain the favourable conditions for capital accumulation by providing a legal and institutional framework that guarantees stability and predictability in its social arrangements (Wood, 2005: 10-14; Harvey, 2005). The state is therefore not a subject nor a neutral terrain, but a social relation in itself (Jessop, 1990; Poulantzas, 1978). As it represents a site for social struggles, the state does not form a unitary block because its different 
institutions might hold a contentious relationship. Despite such differences between state institutions and societal groups like business associations and trade unions, a certain coherence can emerge and be institutionalised over time. This coherence is based on the operational autonomy of the state with regard to pressures emanating from societal groups (Jessop, 1990: 260-262; Jessop, 2008: 37; Brand et al., 2010: 158). This gives the state a 'strategic-relational' character because state power 'reflects the prevailing balance of forces as this is institutionally mediated through the state apparatuses with its structurally inscribed strategic selectivity' (Jessop, 2002: 40). It is the certain degree of independence that the state enjoys which enables this strategic selectivity, understood as the ability of state managers to pursue particular interests and strategies. This can explain why political outcomes sometimes contradict the needs of dominant societal groups, suggesting the continuous importance of the role of class agency in order to secure capitalist hegemony (Van Apeldoorn, 2004: 155).

The transnationalisation of production and finance over the past three decades has given rise to structural transformations that engender transnational social forces and a process of transnational class agency. Transnational fractions of capital have increasingly transcended the borders of the nation-state (Van der Pijl, 1998). An emergent transnational capitalist class is bound together with state managers and intellectuals through common identities and interests by material and ideational structures (Egan, 2001: 77). This implies fundamental restructuring of the national state to advance the agenda of global capitalism, a process referred to as the internationalisation of the state (Cox, 1987). It is thereby important to account for the uneven and distinctive national trajectories of capitalism, however, conditioned by 'the international' (Morton, 2007: 170; Bruff, 2010: 616). The state must be understood as embedded in a network of regulations across different spatial levels, underscoring the uneven character of global capitalism, resulting in a complex spatio-institutional configuration (Wissen and Brand, 2011: 2). The emphasis on the uneven development of capitalism is useful and necessary to account for the different spatial scales of global capitalism articulated through historically contingent state structures. Processes of state internationalisation tend to unfold differently across the world, highlighting the hierarchical relationship between different national modes of development in the capitalist world system. This is a fundamental prerequisite for global capital accumulation and generates relations of dependency among different spatial levels that form part of the world market. With this structural setting, the concrete positioning of each nation in the world market remains informed by the strategic orientation of domestic capitalist classes (Heigl, 2011: 133; Aglietta, 1982; Lipietz, 1984).

Capitalist expansion has led to a situation of unequal exchange between countries integrated into the global economy and policies of free trade tend to intensify these imbalances in trade and production. Consequently, workers around the world are not in the same economic position. Unequal exchange forms thereby the key mechanism of exploitation (Bieler, 2013: 178-180). Free trade agreements constitute therefore mechanisms to lock developing countries into a relationship of unequal exchange and institutionalise guarantees for sustained external transfer of surplus value (Higginbottom, 2013). Free trade agreements are, thus, highly contested projects. The coercive dimension of hegemony is not only manifest in the structural power of capital vis-à-vis subordinate groups, but also in what Gill has identified as 'new constitutionalism' (Gill, 2008), which refers to the politico-juridical lock-in of commitments to disciplinary neoliberalism. As will be argued below, the coercive dimension has become more pronounced and led to an authoritarian-like neoliberalism 
in Peru, which is key to understanding the relationship between organised labour and Peruvian state formation.

\section{The Trade Promotion Agreement's Chapter on Labour and Social Resistance}

From the outset, the trade negotiations, starting on 18 May 2004, centred on traditional trade issues such as market access for agriculture products, textile, sanitary measures, and highly contested issues that were not advanced yet at the WTO, such as investment, services and intellectual property rights. With regard to labour, the negotiations were more or less predetermined by the US. Its fast-track negotiating mandate under the Trade Promotion Authority Act of 2002 stipulated the objective to incorporate fundamental labour rights into future trade negotiations that were already present in its Generalised System of Preferences programmes (USTR, 2013: 21-22). These fundamental rights included: (a) the right of association; (b) the right to organise and bargain collectively; (c) the prohibition on the use of any form of forced or compulsory labour; (d) a minimum wage for the employment of children, and a prohibition of the worst forms of child labour; and (e) acceptable conditions of work with respect to minimum wages, hours of work and occupation safety and health. These fundamental standards reflect the core principles of the 1998 ILO Declaration on Fundamental Principles and Rights at Work, with the notable exclusion of the elimination of discrimination in respect of employment and occupation. Peruvian negotiators have confirmed that although the issue of non-discrimination was left untouched in order not to affect the fast-track status of the agreement's ratification by the US Congress, the US government remained reluctant to include the non-discrimination provision on the grounds that it could elevate labour rights for migrant workers in the US. ${ }^{1}$

The provisions of the agreement's labour chapter centred instead on effective enforcement of the domestic labour laws, which in Peru are far from optimal. The exclusion of the nondiscrimination provision contradicts with Article 17.1(1) of the original TPA text (reprinted in PLADES, 2007), as both parties reaffirm their obligations as members of the ILO and their commitment towards the fundamental rights under the 1998 ILO Declaration. Instead of providing a minimum content guaranteed by both parties, the list of fundamental labour rights did not constitute adequate incentives to elevate labour laws. In the case of wages, the texts were designed to maintain and diffuse the minimum wage whether or not this was sufficient for the survival of the worker (Mendoza Nava, 2009: 154). Furthermore, both parties 'shall not fail to effectively enforce its labour laws through a sustained or recurred course of action or inaction, in a manner affecting trade between the Parties, after the date of entry into force of this Agreement' (Art. 17.2(1a), original TPA text). This is the only labour provision that is formally enforceable under the dispute resolution mechanism, in sharp contrast to all provisions pertaining to commercial interests that are enforceable through the formal and separate dispute resolution mechanism. The TPA includes provisions on openness and transparency in labour dispute resolution and forces governments to accept and investigate social complaints on corporate violations of labour laws according to domestic procedures (Art. 17.3(2;3); Art. 17.4; Art. 17.6(1;7)). The latter implies that despite the obligation to hear social complaints, these would not necessarily lead to government action (PLADES, 2007: 23-28). Moreover, the dispute resolution mechanism on labour issues is only applicable to productive sectors that participate in bilateral trade with the US. In other words, companies whose participation in bilateral trade with the US is non-existent, uncertain or non-demonstrable can very well escape the 
labour monitors and sanctions (Mendoza Nava, 2009: 155). Hence, the adequate enforcement of the labour clauses came to rely on the institutional capacity of the Peruvian state.

The weak content of the labour chapter, together with other major concerns in the field of agriculture, intellectual property rights and human rights, has provoked fierce criticism among Peruvian social organisations. In the context of trade liberalisation, many agrarian, indigenous and extractive industry movements have created a huge movement within the rural areas and have sought alliances with the urban labour movements. This culminated into the national campaign TLC jAsi No! (FTA not like this!) under the leadership of the National Convention of Peruvian Agriculture (CONVEAGRO) with international support from Oxfam. The campaign had its direct antecedent in a larger platform that criticised Peru's participation in the Free Trade Area of the Americas (FTAA) between 1998 and 2003. Peru's main trade unions the Peruvian Labour Confederation (CGTP) and Unitary Workers Confederation (CUT) as well as traditional peasant organisations such as the National Agricultural Confederation (CNA) and Peasant Confederation of Peru (CCP) have been part of a coalition that completely opposed the FTAA (Burneo de la Rocha, 2009). These urban and highland organisations, led by anti-neoliberal and anti-imperialist sentiments, were more militantly opposed to any sort of trade agreement at all.

Rather than being a homogeneous organisation, within the structures of the campaign, there were strong internal struggles between its different members. Both CNA and CCP formed part of the larger CONVEAGRO that emerged out of new forms of non-traditional agriculture along the coast as well as new sorts of small-to-medium-scale producers oriented toward market and product specialisation. While these were more concerned with compensation mechanisms for the expected damages, highland organisations worried more about the wider ramifications of the TPA for control of territory, access to resources, and food security (Bebbington, 2010: 17). Also Peru's trade unions held different views on the TPA. Unions closely related to Peru's labour party American Popular Revolutionary Alliance (APRA) accompanied the government and business elites in supporting the agreement (La República, 2007). On the other hand, Peru's main trade unions CGTP and CUT were ideologically opposed to the TPA and lifted their criticism to neoliberal restructuring in general. Evidently, the division among these different social forces limited the presence of a united national campaign for another type of TPA, whose leadership was eventually reduced to a small number of individuals.

Moreover, the government put little effort to include social organisation representatives in the trade negotiations and the official consultation remained rather poor. Government officials declared that consultations with trade unions and other social movements were less helpful than those undertaken with business as their criticism was not directly related to the TPA and, thus, little useful in the formulation of negotiating positions. ${ }^{2}$ Close personal ties between high state officials and business representatives, on the other hand, greatly enhanced coherence between the public and the private sector, strengthening the formation of a powerful pro-TPA coalition. The rhetoric of the political elite that the TPA would favour all Peruvians seemed appealing, and critical groups lacked political room and economic resources for a strong countermovement. Hence, trade unions and social movements remained incapable of influencing official TPA proposals and the major concerns remained at the grassroots level, which became manifest in massive mobilisations and strikes. The embracement of the TPA by Peru's labour party APRA in the final vote on 28 June 2006 meant a decisive defeat for organised labour. The cooptation of APRA by the powerful hegemonic forces has marked its relationship with the rank and file grassroots movements by a major gap. 


\section{Labour as Determinant for the Trade Promotion Agreement}

After approval in Peru, the trade agreement came to depend on the ratification by the US Congress. Influential voices in the US had criticised the hasty nature of the negotiations and raised serious doubts about the commitment of the Peruvian government to the labour standards incorporated into the TPA (PLADES, 2007). With a Democratic majority in the US Congress after the mid-term elections in November 2007, a new consensus with United States Trade Representative (USTR) resulted in a 'New Trade Deal' that allowed for certain flexibilities in intellectual property rights, and elevated labour, environmental and investment standards in the pending trade agreements with Peru, Colombia, Panama and Korea (USTR, 2007). Although fiercely rejected by Peru's state technocrats and industrial leaders, the proposed amendments had to be accepted in order to secure the TPA's ratification by the US Congress. ${ }^{3}$ However, the US Congress was not authorised to amend the TPA since it had delegated temporal powers to USTR under the Trade Promotion Authority Act in 2002. Eventually, the decision of the Peruvian government to negotiate directly with the US Congress marked an important step towards the TPA's ratification in the US, whereas the other remaining Andean partner, Colombia, continued to negotiate with USTR, resulting in a stalemate precisely because of labour and human rights concerns by the US Congress.

The amendments on labour issues incorporated certain important repercussions. Article 17.2 on the fundamental labour rights explicitly mentions the obligation to adopt, maintain and enforce in national statutes and regulations the fundamental rights of the 1998 ILO Declaration. The elimination of discrimination in respect of employment and occupation has been included. The new text also eliminates the reservation by means of which the right of parties to adopt or modify labour laws and standards is reaffirmed, seeking to ensure that these are consistent with the mentioned fundamental labour rights. With regard to the enforcement of labour laws (Art. 17.3), it was previously mentioned that the parties should not fail to effectively enforce its labour laws in a manner affecting trade. This obligation has been widened to including the laws on mentioned fundamental labour rights in a manner affecting trade or investment. Moreover, the scope of dispute resolution has been broadened from the narrow non-application of domestic labour laws to any issue of the chapter, including breaches of the fundamental labour rights (PLADES, 2007: 32). The Peruvian government under the leadership of president and APRA leader Alan García eagerly adopted the protocol of amendments and the concomitant promises to change laws with regard to precarious employment in Peru relieved the last remaining US doubts, ${ }^{4}$ greatly facilitating the TPA's ratification in US Congress on 4 December 2007.

Although embracing the amendments to the trade agreement, Peruvian trade unions remained sceptical about the true intentions and commitments to labour issues by president García and his government. In particular, the CGTP and the CUT have demanded the approval of new labour legislation in line with the ILO conventions, including the adoption of a General Labour Law that would integrate Peru's scattered labour laws and decrees into one code, which has been constantly resisted by consecutive governments and national business. ${ }^{5}$ High doubts about the institutional capacity of the Peruvian state to implement the amended labour standards remained and trade unions demanded greater budget allocation to the Ministry of Labour and Employment Promotion. Frequent fines and financial punishments for incompliance with the labour standards under the TPA's dispute resolution mechanism are expected to affect Peru's state budget; in addition, non-payment of such fines can lead to temporary suspension of trade benefits (Fairlie and 
Quejía, 2007: 134). Other groups feared that the maquila development in Peru would threaten people as cheap labour without ensuring decent work conditions. Increased competition from US multinationals is expected to outcompete Peruvian companies, forcing many workers into the informal sector without labour protection. ${ }^{7}$ The displacement of rural workers and producers is likely to increase rates of drug trafficking, violence and terrorism. On the other hand, although accepting the imposition of the amendments as a bitter drink to secure the TPA, Peruvian business groups have continued to demand for greater labour flexibility to remain internationally competitive. The structural weakness of trade unions and social movements to influence the course of events and the responsiveness of the Peruvian state towards private interests have be to understood against the backdrop of the broader transformation of Peru's political economy and the state.

\section{The Transformation of Peruvian State-Society Relations}

Unlike many of its Latin American counterparts, Peru's economy, centring on an exportoriented economic model, remained relatively market-friendly and non-interventionist well into the 1960s. Long periods of oligarchic rule, authoritarianism and external influences generally had failed to redistribute economic growth and reinforced social inequalities in Peruvian society (Cameron, 2011: 378). The military coup of 1968 put an abrupt end to the primary export based economy. The regime of General Juan Velasco Alvarado (1968-1975) introduced ambitious reformist and state-led development policies that sought to promote land reform, industrial communities, rapid unionisation and generous wage settlements (Solfrini, 2001: 109). Peruvian labour movements generally welcomed the efforts of the military regime to organise labour, promote employment security and reinforce legal rights of unions (Roberts, 1998: 210). Organised labour has traditionally been affiliated with the populist APRA party. The Peruvian Labour Congress (CTP), created by APRA in 1944 has been Peru's largest labour confederation until the 1960s, after which APRA started to rely on coalitions with conservative blocks (Levitsky and Mainwaring, 2006: 28; Solfrini, 2001: 110). The strategic shift of APRA spurred many unions to abandon the CTP and by the early 1970s, the Peruvian Labour Confederation (CGTP) had become Peru's main labour confederation with a leadership dominated by the Peruvian Communist Party (Levitsky and Mainwaring, 2006: 29).

Simultaneously, ambitious agrarian reforms led to the expropriations of coastal plantations and highland haciendas, which were transformed into agricultural cooperatives managed by their former workers. However, these reforms benefitted only a small portion of the peasantry. The vast majority of temporary agricultural workers and indigenous groups remained outside the scope of the reforms (Roberts, 1998: 210-212). When the military regime started to implement austerity measures prescribed by the International Monetary Fund (IMF) in response to the deteriorating economic prospects, strong popular opposition contributed to the unification of various social organisations in organising massive general strikes in 1977-1978 (Solfrini, 2001: 111; Roberts, 1998: 211-13). Although the CGTP supported the military regime even after its shift to the right in 1975, it joined the more radical unions in the anti-government marches, which eventually played an important role in pushing Peru's transition towards democracy (Levitsky and Mainwaring, 2006: 3536).

The economic reforms of the military regime were reversed with the presidency of Fernando Belaúnde Terry (1980-1985), whose liberal orientation gave primacy to improving the national 
manufacturing sector by reducing production costs in order to become internationally competitive (Solfrini, 2001: 113). Tariffs were drastically reduced, state subsidies were lowered and the Peruvian economy became gradually opened up for foreign capital, however, without success: industrial production declined to $17.2 \%$ in 1983; unemployment reached 68\% in 1984 and between 1979 and 1984 wages lost 30\% of their purchasing power (ibid.: 113). These first neoliberal market reforms were pragmatic and instrumental rather than ideological, and far from hegemonic (Arce, 2005: 33). Heavily subsidised national industrialists strongly opposed the liberalisation of the Peruvian market, after which the government decided to withdraw the trade liberalisation efforts. Leftist organisations and unions also rejected the orientation towards the external market, but had been seriously weakened after confrontation with the military regime (Solfrini, 2001: 113). Moreover, radical Maoists from the Shining Path emerged out of the failure of land reform in the poorest highland departments and launched a vicious campaign of insurgency throughout the country (Cameron, 2011: 378).

With the presidency of APRA leader Alan García Pérez (1985-1990), the market reforms were further reversed. His heterodox economic project was initially based on the organisation of a large solidarity pact among popular masses, national entrepreneurs and state institutions (Solfrini, 2001: 116). Economic policies of wage increments, price controls and tax breaks to stimulate aggregate demand booked some success and generated a brief economic boom in 1986-1987 (Roberts, 1998: 236). To reinforce state intervention, García unilaterally reduced the external debt payment to $10 \%$ of the value of exports, after which Peru became ineligible for further credit, thereby isolating Peru from the international financial community (Solfrini, 2001: 117). Foreign exchange constraints and increased government deficits led to renewed inflationary pressures by 1987, mounting up to a record of 7,649\% in 1990 (Arce, 2005: 35). The economic adjustment programmes carried out in response to the crisis ultimately generated the worst economic decline in Peru's history. Industrial production decreased with over a third between 1988 and 1990, leading to dropping wages, massive unemployment and informalisation of the labour force (Roberts, 1998: 237-242).

The heterodox economic policies promoted by García's government gave rise to increased opposition from Peruvian conglomerates and from foreign capital. Particularly, García's attempt to nationalise the banking sector in 1987 put a definite end to any further agreement with the national capitalist class. These market forces started to develop various strategies to counteract their decreasing institutional influence. One important strategic step was the foundation of a new umbrella organisation, the Confederation of Private Business Institutions (CONFIEP). Though created in 1984, the attempts to nationalise the banks prompted a collective capitalist counteroffensive in alliance with right-wing opposition forces led by novelist Mario Vargas Llosa that eventually succeeded in stopping its implementations (Durand, 1998: 266). While the neoliberal state project started to crystallise out with the ascendency of these neoliberal forces, APRA's economic mismanagement and the civil war still raging inside Peru seriously undermined the position of Peru's leftist organisations and trade unions. The growing distrust of Peruvians in traditional political parties gave way for a political outsider. The newly elected president Alberto Fujimori (1990-2000) aimed at the gradual adjustment of economic policies compared to the neoliberal shock-therapy as proposed by Vargas Llosa. Once in office, Fujimori travelled to Washington where he met with the representatives of the international financial community. The message was clear: apply an immediate liberalisation programme and secure the reinsertion of Peru 
into the international financial community (McClintock and Walls, 2003: 94). Once back in Peru, Fujimori started to implement neoliberal policies based on stabilisation and structural adjustment programmes with international financial support.

With reinforced ties to the international financial community, the neoliberal state project gained momentum and the policies employed by the Peruvian state became rapidly neoliberal. The ascendency of state technocrats contributed to the internationalisation of the Peruvian state as these were often aligned with dominant economic ideas originated particularly from the US (see also Heigl, 2011; Teichman, 2001). The process of internationalisation of the Peruvian state has also generated institutional restructuring. Institutions dealing with international economic affairs such as the Ministries of Economy and Finance, Foreign Relations, and Foreign Trade gained influence at the cost of institutions dealing with internal affairs, such as the Ministries of Labour and Employment Promotion, Production, and Agriculture (Durand, 2003, 2005; see also Cox, 1987; Teichman, 2001). Under the so-called Fuji-shock, price controls and almost all government subsidies were eliminated, and the service of debt payments - about $\$ 60$ million a month - were resumed. Due to unsatisfactory results, the Fujimori-administration carried out a new reform package by decree law that encompassed the total deregulation of markets, privatisation of state-owned companies and activities and a tight monetary fiscal policy (Gonzales de Olarte, 1998: 32; McClintock and Walls, 2003: 94-95).

The internalisation of such neoliberal restructuring did not come about without considerable struggle. Faced with increased political opposition to his neoliberal agenda, Fujimori dissolved the Congress by means of a 'self-coup' (autogolpe) on 5 April 1992. Only after external pressure from the IMF and the World Bank, which temporarily suspended their loans to Peru, Fujimori installed a new Congress in 1993 by popular referendum (Arce, 2005: 43). The autogolpe greatly enhanced Fujimori with extraordinary powers to accelerate his neoliberal reforms as well as brutal counterinsurgency through presidential laws and decrees. The subsequent massive wave of privatisations attracted foreign direct investment in natural resources, consumer markets and the financial sector, particularly from the United States (McClintock and Walls, 2003: 99). The neoliberal restructuring, privatisations and resulting joint-ventures resulted in an intense concentration of ownership and productive capacity that is increasingly transnational in scope, thereby diminishing the political leverage of Peruvian nationally-oriented industrial groups and small-and-medium enterprises (Durand, 2005: 212-213).

In less than three years, Fujimori succeeded in restoring political order by resolving Peru's most pressing problems. Sustained economic growth started in the second half of 1992; GDP grew to $8.6 \%$ annually between 1993 and 1995 and inflation dropped to $48 \%$ in 1994 and $11 \%$ in 1995 (Central Reserve Bank of Peru, 2013). Moreover, the capture of Shining Path leader Abimael Guzmán in September 1992 meant a decisive defeat for insurgent forces, thereby virtually ending more than a decade of bloodshed that had cost approximately 70,000 lives (Truth and Reconciliation Commission, 2003). With these accomplishments, Fujimori secured his re-election in 1995 with a landslide victory, contributing to confidence and optimism among investors. On the other hand, labour and farmer movements experienced a declining political role under the semiauthoritarian regime. As social movements became increasingly marginalised and exhausted from the civil war during the 1980s and 1990s, Fujimori's neoliberal policies, combined with clientelism and populist strategies in order to wipe out all collective social action, further aggravated their situation (Bebbington et al., 2008: 11). 
During the last two years of Fujimori's regime, his authoritarian character increasingly began to threaten economic stability and growth (Arce, 2005: 146). Imports started to outnumber exports due to the East-Asian crisis and the El Niño weather phenomenon that damaged Peruvian exports (ECLAC, 1998). Criticism on the free-market model arose since Fujimori was only keen on being re-elected. As evidence of widespread corruption accumulated, public legitimacy of his tenure vanished completely, forcing Fujimori to flee the country (Durand, 2003, 2005; Arce, 2005). After a brief spell of political unrest, the election of former World Bank employee Alejandro Toledo (20012006) as new president in 2001 initiated a process of democratisation. Despite the fragile political basis of Toledo's presidency, its orientation remained dependent on the neoliberal hegemony and the strength of the primary export economy under the leadership of transnational corporations. His policies were centred on macroeconomic stability that formed an impulse for a second generation of market reforms (Tanaka, 2005: 29). Key positions in Toledo's administration were all strongly connected to foreign and national capital related to exports or finance, continuing the inherited orientation from the preceding regime without major adjustments (Durand, 2003). While macroeconomic policies led to an unprecedented economic growth, little would trickle down to the poorer regions located in the southern and central highlands and the Amazon (Cameron, 2011: 379). Although the demise of Fujimori brought greater openness and democracy, it did not lead to greater political participation by labour and other social organisations. Whereas the Congress has indeed become more receptive for societal demands, the executive has in fact become more closed and nearly inaccessible (Bebbington et al., 2008: 13). Consecutive governments have continued to block reforms to Fujimori's labour laws and freely use state power to suppress social and labour movements.

\section{Labour Exploitation in Peru's Export-Oriented Regime of Accumulation}

The capitalist restructuring of Peru's political economy has shaped new economic structures and patterns of capital accumulation and surplus extraction. In particular, trade liberalisation became one of the major targets of Toledo's government. The pro-free trade policies were eventually eased by the newly created Ministry of Foreign Trade and Tourism (MINCETUR). Consequently, free trade proponents were recruited and the consecutive ministers have all been related to the free market discourse. One of its first achievements was the expansion of earlier granted trade preferences under the Andean Trade Preference Act (ATPA) of 1991 with the launch of the Andean Trade Promotion and Drug Eradication Act (ATPDEA) in 2002. The ATPDEA would expand private sector opportunities and investment in the non-traditional sectors of the Andean countries as an alternative to the production of coca and help them diversify their economics and expand their exports (Wise and Quiliconi, 2010: 30-31). In addition, Peruvian exports enjoyed also preferential access under the US Generalised System of Preferences (GSP) that sought to promote economic growth of developing countries by stimulating exports.

Both programmes created an upsurge in Peruvian exports to the United States. Particularly, the ATPDEA preferences benefitted the agricultural export and the textile-apparel sectors. Agricultural exports to the US under the ATPDEA increased from \$209.6 million in 2003 to $\$ 314.2$ million in 2005; simultaneously, Peruvian textile exports expanded from $\$ 469.2$ million in 2003 to $\$ 821.2$ million in 2005 (Alayza, 2007: 145). In addition, it is estimated that 106,000 direct and indirect jobs depend on the export of textile and apparel, whereas the ten most exported 
agricultural products alone generated 350,000 jobs in 2005 . In total, approximately 744,000 Peruvians have jobs directly or indirectly depending on exports that enter the US duty-free under the ATPDEA (MINCETUR, 2005a: 11-15; MINCETUR, 2005b: 5-6). Consequently, national entrepreneurs and state technocrats portrayed the possible losses in case of expiration of the ATPDEA and, to a lesser extent, GSP schemes as a 'scary scenario' (MINCETUR, 2005a) and started to push for a bilateral free trade agreement that would make the preferences permanent. At the same time, agricultural sectors dedicated to subsistence and production for the internal market, characterised by labour-intensive and pre-modern production structures in the rural areas, would face a decline in production and employment levels with the TPA. According to MINCETUR (2005c: 9-11), the TPA would generate a more 'efficient allocation' of workers between productive sectors, displacing them from traditional agricultural sectors such as wheat, rice, cereals and grains, to non-traditional sectors such as vegetables, fruits and nuts, which are characterised by modern, capital-intensive and highly competitive export-oriented sectors located in Peru's coastal areas.

As such, the dynamics of the TPA stood to reinforce the juxtaposition of the two existing and competing agricultural models that have come to reflect Peru's deeper and historical cleavages. The commercial benefits under the new export-oriented regime of accumulation have indeed been highly unequally distributed. Only $3 \%$ of Peru's cultivable lands is dedicated to agricultural exports, which represents a mere 9\% of the GDP for the agricultural sector (CEPES/CONVEAGRO, 2006: 21). However, more than $90 \%$ of the direct impact of increased agricultural exports under the ATPDEA has been concentrated in the Lima-area and along the coastal strip. Simultaneously, with the TPA in force, half of the sensitive products would receive immediate tariff reduction, which would affect more than one million producers and their families that are located in the rural and poorest zones in Peru (Alayza, 2007: 146, 161).

The expansion of the neoliberal export-oriented model has led to major macroeconomic growth after the fall of Fujimori. GDP rates increased from 5\% in 2002 to $9.8 \%$ in 2008 before a sharp plunge to $0.9 \%$ in 2009 in the wake of the global crisis (Central Reserve Bank of Peru, 2013). Also formal urban employment rates have been growing during the same period from negative in 2002 to $8.3 \%$ in 2008 before declining to $1.4 \%$ in 2009 (Gamero Requena, 2010: 18). However, macroeconomic prosperity has not been translated into improved conditions for Peruvian workers. The adoption of competitive policies brought about a wide range of legal reforms in order to restructure labour relations in line with the orientation of the neoliberal state project. During the period when most of the country's new jobs were created, labour market conditions actually deteriorated. Labour in export-oriented production sectors is characterised by low wages, considerable job insecurity, overtime and low levels of unionisation.

In absence of a unified labour code, labour laws and regulations are scattered among approximately 50 different bodies of Peruvian laws. Peru's most relevant labour law is codified in the Productivity and Competitiveness Law (No.728), adopted by Fujimori in 1997, which legalises dismissals without justification, allows flexibility, and permits collective dismissals, often used to fire pro-union workers (Solidary Center, 2009: 7, 13). Moreover, labour relations in Peru's most competitive sectors have been governed by a separate regime of labour laws. In particular, the Decree on the Promotion of Non-Traditional Exports (No. 22342) allows employers to hire workers on a series of short-term contracts that can be renewed without requiring hiring the worker permanently, severely affecting the workers' ability to organise unions. Evidently, unionisation rates in the textile and agricultural industry sectors are low and workers remain reluctant to form a union or join an 
existing one in fear of repercussions of the employer (SOMO, 2011a; 2011b). In addition, the law on the Promotion of Agriculture (No. 27360) of 2000, applying only to agricultural sectors, replaced the eight-hour day standard with an 'accumulated workday' formula, while the minimum wage in the agricultural sector includes accrued benefits and bonuses in comparison to non-agricultural workers (Solidarity Center, 2009: 18-19). As a result, the vast majority of agricultural workers lack a formal contract and health insurance, unionisation rates are below national average and working hours are longer (Gamero Requena, 2010: 28-30). Although intended as a special and transient labour regime to stimulate investments in agriculture in the 1990s, this particular law was extended until 2012 by Congress in 2006 (RedGE, 2012).

The transformation of the Peruvian state and the concomitant internationalisation processes have had severe repercussions for the institutional capacities to enforce labour standards according to the core principles of the International Labour Organisation (ILO). At the time of the negotiations, Peru's Ministry of Labour and Employment Promotion received less than 1\% of the national budget and lacks sufficient resources to inspect compliance with fundamental labour rights (ADL, 2007: 12). Although numerous international labour rights conventions have been ratified and implemented into national legislation, estimates suggest that Peru violates more than half of them (Mujica Petit, 2009: 38, 104). These violations culminate in the export-oriented sectors of the Peruvian economy, whereas the labour situation in export-processing-zones (EPZs) tends to be worse (ADL, 2007: 27; Solidary Center, 2009: 6). Consequently, union movements and employment stability have been seriously weakened. Despite government promises to implement programmes of 'decent work' as outlined by the ILO, breaches of fundamental labour rights are the order of the day.

\section{Strategic Selectivities and Coercion Under the Garcia Administration}

The presidential elections of 2006 provided a window of opportunity for counter-hegemonic forces in Peruvian society. The growing social dissent with the pro-market policies and the lack of adequate political linkages created the conditions for new leftists movements as had been occurring in Peru's Andean counterparts, culminating in massive support for the nationalist and former military leader Ollanta Humala. Although Humala won the first round of the presidential elections, APRA's constituency in the coastal and urban areas as well as the support by the neoliberal hegemonic forces resulted in a win for former anti-imperialist and state interventionist Alan García. The vested interests in consolidating the economic model based on exports and free trade became well-embedded in his surprisingly changed discourse. Despite a electoral campaign based on an eloquent critique of the neoliberal model, García increasingly relied on centre-right forces in Congress as well as neoliberal technocrats in pursuing orthodox macroeconomic policies once in office (Cameron, 2011: 388-389). Although producing annual growth rates between 7\% and $9 \%$ in the first three years of APRA rule, his government, at the same time, failed to make social investments that would bring economic resources generated by the commodity-led growth to the impoverished regions of the country. García's rapid embracement of the TPA constitutes the lock in of the neoliberal orientation, exacerbating the fractures in Peru's social structures. The hegemony of the export-oriented economic model has become more contested and Peruvian state leaders increasingly rely on the frequent use of coercive methods to secure continued and expansive processes of surplus extraction and capital accumulation. 
The neoliberal strategic selectivity appears in the way in which the state addresses particular interests or strategies among neoliberal forces. In particular, the strategic selectivity of the institutional terrain allowed neoliberal forces to warrant favourable conditions for an optimal accumulation of capital. This capacity has become manifest through a series of legislative decrees with dubious constitutional validity, that were deemed necessary to implement the TPA but, instead, entail a much broader regulatory modification of Peruvian legislature aimed to facilitate access to natural resources, private investment and infrastructure (Eguiruren Praeli, 2008: 14-20). Particularly, environmental groups and Amazonian indigenous groups have been mobilised by the decrees that seek access and commodification of collectively held lands in order to expand oil production and private investment. The APRA administration has faced increasing strike activities, including teachers protesting against educational reforms and miners objecting to the use of casual labour (Cameron, 2011: 392). Faced with the prospects of social protests transforming into political movements, the government has resorted to the condemnation and even criminalisation of protests that blocked the government's priorities (Bebbington et al., 2008: 14). This attitude has been promoted by president García himself in a series of articles in Peru's main newspaper El Comercio (García Pérez, 2007), in which he accuses opposition to his administration's ideas and policies as 'dissenters' who hinder Peru's modernisation, consigning them to the status of the 'dog in the manger'.

With regard to labour, various legislative decrees directly reverse some of the TPA agreements. Decree 1057 reduces benefits for public sector worked hired under administrative service contracts, whereas decree 1025 obliges public workers to undergo frequent performance evaluations, imposing a punitive logic to fire workers who do not pass such state assessments (Solidarity Center, 2009: 7; Mujica Petit, 2009: 62). Moreover, decree 1086 to Promote Competitiveness, Formalisation and Development of the Micro- and Small Enterprise and Access to Decent Employment substantially weakens the terms and conditions for workers in micro- and small enterprises as workplaces of 100 or fewer workers (previously 50) enjoy less vacation, lower pay, and even less compensation if unjustly dismissed (Solidarity Center, 2009: 7). Considering the high representation of micro- and small enterprises in the Peruvian economy, decree 1086 is argued to cover more than $80 \%$ of all workers, thereby affecting fundamental labour rights for a vast collective of workers (Mujica Petit, 2009: 71-73; RedGE, 2010). Moreover, decree 1038 reduces the scope of Peruvian law that puts a hold on abusive practices of subcontracting or tertiarisation, which has been one of the most invoked mechanisms to circumvent labour rights and to impede unionisation, particularly in the export-oriented agriculture, mining and hydrocarbons sector (Mujica Petit, 2009: 78-79; Bebbington, 2010: 20).

Meanwhile, parliamentary debates over a General Labour Law that would grant workers with greater protection against unfair dismissals and restore the right to collective bargaining per industry, have been paralysed since 2002 (ADL, 2007: 22. The deadlock in talks over such initiatives reflects fierce resistance from the dominant state institutions and corporate power groups. When USTR finally gave the green light for the coming into effect of the TPA on the last day in office, 16 January 2009, Peru was still failing to comply with the new labour standards as well as several other legislative modifications (Gamero Requeno, 2010). The forthcoming entrance of the newly elected Barack Obama to the White House on 20 January 2009 might have rushed the implementation process and its eventual approval. Meanwhile, it has become clear that the hopes and predictions of TPA proponents have failed to materialise. Labour conditions in Peru have deteriorated rapidly since 
the coming into force of the trade deal. Potential benefits were almost immediately nullified with the waking global financial and economic crisis; concomitantly, the sharp plunge in employment rates in 2009 revealed the structural vulnerability of workers operating in the export-oriented sectors.

\section{Conclusion}

This article has examined the labour dimension of the US-Peru Trade Promotion Agreement and its broader ramifications for labour relations in Peru's new regime of accumulation. Despite the inclusion of a labour chapter in the trade agreement that forces both parties to abide by international conventions on fundamental labour rights, much of its actual enforcement has come to rely on the institutional capacities of the Peruvian state and its engagement with labour and human rights protection. The central argument is that the political processes that have influenced the course of events leading to the TPA have to be understood against the backdrop of the wider transformation of the balance of social forces, which has come to reflect the material and institutional dominance of the neoliberal sectors of the Peruvian society. The profound restructuring of Peru's social relations has given rise to a neoliberal project that is oriented towards the opening of new fields for capital accumulation through the commitment to massive deregulation, privatisation and liberalisation programmes. This has culminated into a new regime of accumulation that is based on a highly profitable export-oriented growth model, which, at the same time, is characterised by severe forms of labour exploitation. The extraordinary expansion of exports has mobilised privileged lobbies in favour of the TPA that would gain disproportionately from further trade liberalisation while losses for the population at large would be more probable. These patterns of surplus extraction have ultimately become 'locked in' by the disciplinary nature of the TPA.

The structural weakness of organised labour and social movements has been further aggravated by the ascendency of the neoliberal state. Whereas neoliberal forces enjoy privileged access, the neoliberal strategic selectivity has limited the institutional openings for the political articulation by trade unions and social organisations. In fact, with state power increasingly concentrated in the executive branches under the García-administration, political dissent has become increasingly delegitimised, marginalised and criminalised. As such, the Peruvian state has come to rely on coercive methods to sustain profitable modes of surplus extraction and offensively attacks opposition movements that are not in line with it. Although new hopes for change arose with the election of Ollanta Humala in 2011, the export-oriented policies remain to fracture Peru's deeply rooted historical and geographical cleavages. With social conflicts continuing to increase, reflecting the underlying class struggles, the search for greater profits has been accompanied by greater rates of exploitation and increased pressure on the workforce. The repressive management of labour relations and natural resources in favour of transnationally-oriented sectors constitutes a key mechanism in securing an ongoing process of surplus extraction and the transfer of value from the periphery to the North. The efforts by the Peruvian government to vilify workers and local communities have indeed contributed to a stable investment environment sustaining economic growth, albeit, one that takes place in a permanent state of emergency. 


\section{NOTES}

1. Interview, Vice-Minister of Labour 2004-2005, 1 July 2009.

2. Interview, trade official, Vice-Ministry of Foreign Trade, 31 July 2009.

3. Ibid.

4. Letter to US Congress by Charles Rangel and Sander Levin, Committee on Ways and Means, 10 September 2007. Reprinted in PLADES (2007).

5. Letter to the Speaker of the US House of Representatives by CGTP, CUT, Health Forum and National Confederation of Pensioners and Retired Persons of Peru, 11 May 2007. [Online] Available at http://www.citizenstrade.org/ctc/wp-content/uploads/2011/05/CartaaPelosi SeguridadSocialTLC_Ingles.pdf [Accessed: 2 January 2014].

6. Letter to US Congress by CGTP and CUT, 20 August 2007. [Online] Available at http://www.citizenstrade.org/ctc/wp-content/uploads/2011/05/PeruvianLaborUnionLetter_ 082007.pdf [Accessed: 2 January 2014].

7. Letter to US Congress by US and Peruvian women, 3 November 2006. [Online] Avialable at http://www.citizen.org/documents/USGTNPeruFax.pdf [Accessed: 2 January 2014].

\section{ACKNOWLEDGEMENTS}

I would like to thank Laura Horn and Mònica Clua-Losada and the two anonymous referees for their helpful comments and suggestions.

\section{REFERENCES}

Alianza por los Derechos Laborales (ADL) (2007) Análisis de los desafíos que el gobierno peruano debe encarar a la luz del Capitulo laboral del Tratado de Libre Comercio Perú-Estados Unidos. Lima: RedGE.

Aglietta, M. (1982) 'World Capitalism in the Eighties'. New Left Review. 136: 5-42. 
Alayza, A. (2007) 'Blindar la Economía de la Política: A un Año de la Aprobación del Tratado de Libre Comercio Perú-Estados Unidos', in: DESCO (Ed.) Perú Hoy: Un Año sin Rumbo, un Gobierno con Pasado. pp. 139-176. Lima: DESCO.

Arce, M. (2005) Market reforms in society. Post-crisis politics and economic change in authoritarian Peru. University Park Pennsylvania: Pennsylvania State University Press.

Bieler, A. (2013) 'The EU, Global Europe, and Processes of Uneven and Combined Development: The Problem of Transnational Labour Solidarity'. Review of International Studies. 39(1): 161-183.

Bebbington, A. (2010) Social movements and poverty in developing countries. Civil society and social movements programme paper number 32, United Nations Research Institute for Social Development.

Bebbington, A., Scurrah, M. and Bielich, C. (2008) Mapping current Peruvian social movements. Manchester, Lima: University of Manchester, CEPES.

Brand, U., Görg, C. and Wissen, M. (2010) 'Second-order condensations of societal power relations: environmental politics and the internationalization of the state from a neo-Poulantzian perspective'. Antipode. 43(1): 149-175.

Bruff, I. (2010) 'European Varieties of Capitalism and the International'. European Journal of International Relations. 16(4): 615-638.

Burneo de la Rocha, M.L. (2009) 'La Movilización de los Agricultores frente al TLC Perú-Estados Unidos: Hipótesis para la Discusión’. Debate Agrario. 43, 61-87.

Cameron, M.A. (2011) 'Peru: The Left Turn that Wasn't', in S. Levistky and K.M. Roberts (Eds.) The Resurgence of the Latin American Left. pp. 375-398. Baltimore: John Hopkins University Press.

Central Reserve Bank of Peru (2013) Statistics, Annual Tables, [Online] Available at http://www.bcrp.gob.pe/statistics/annual-tables.html [Accessed: 15 January 2014].

CEPES/CONVEAGRO (2006) Impacto de la Eliminación del Sistema Peruano de Franja de Precios y Opciones Politicas para Compensar sus Efector en el Sector Agrario. Informe Final. Lima: CEPES/CONVEAGRO.

Cox, R.W. (1981) 'Social forces, states and world orders: Beyond international relations theory'. Millenium: Journal of International Studies. 10(2): 126-155.

Cox, R.W. (1983) 'Gramsci, hegemony and international relations: An essay in method'. Millenium: Journal of International Studies. 12(2): 162-175. 
Cox, R. W. (1987) Production, power, and world order. New York: Columbia University Press.

Durand, F. (1998) 'Collective action and the empowerment of Peruvian business', in F. Durand and E. Silva (eds.), Organized business, economic change, democracy in Latin America. Miami: North-South Center Press, University of Miami, pp. 253-280.

Durand, F. (2003) Riqueza económica y pobreza politica. Reflexiones sobre las elites del poder en un país inestable. Lima: Fondo Editorial, Pontificia Universidad Católica del Perú.

Durand, F. (2005) La mano invisible en el estado. Efectos del neoliberalismo en el empresariado y en la politica. Lima: Fundación Friedrich Ebert.

ECLAC (1998) Impact of the Asian Crisis on Latin America. Santiago: ECLAC.

Egan, D. (2002) 'The limits of internationalization: A neo-Gramscian analysis of the multilateral agreement on investment'. Critical Sociology. 27(3): 74-97.

Eguiruren Praeli, F.J. (2008) Análisis de la conformidad constitucional del uso de las facultades legislativas otorgadas por el congreso al poder ejecutivo mediante la ley no. 29157. Lima: Oxfam America.

Fairlie, A. and Quejía, S. (2007) 'Adendas del TLC: ¿Benefician al Perú?'. Cuadernos Latinoamericanos. 18: 113-137.

Gamero Requena, J. (2010) Empleo y trabajo decente a un año del TLC con EE.UU. Lima: RedGE.

García Pérez, A. (2007) ‘El sindrome del perro del hortelano’, El Comercio. 27 October 2007.

Gill, S. (2008) Power and resistance in the new world order. New York: Palgrave MacMillan.

Gonzales de Olarte, E. (1998) El neoliberalismo a la peruana. Economía politica del ajuste estructural, 1990-1997. Lima: Instituto de Estudios Peruanos, Consorcio de Investigación Económica.

Gramsci, A. (1971) Selections from the prison notebooks. New York: International Publishers.

Harvey, D. (2005) A Brief History of Neoliberalism. New York: Oxford University Press.

Heigl, M.C. (2011) 'Social Conflict and Competing State Projects in the Semi-Periphery: A Strategic-Relational Analysis of the Transformation of the Mexican State into an Internationalized Competition State'. Antipode. 43(1) 129-148.

Higginbottom, A. (2013) 'The Political Economy of Foreign Investment in Latin America'. Latin American Perspectives. 40(3): 184-206. 
Horn, L. (2012) 'Anatomy of a 'Critical Friendship': Organized Labour and the European State Formation'. Globalizations. 9(4): 577-592.

Jessop, B. (1990) State theory. Putting the capitalist state in its place. Cambridge: Polity Press.

Jessop, B. (2002) The future of the capitalist state. Cambridge: Polity Press.

Jessop, B. (2008) State power. Cambridge: Polity Press.

Joseph, J. (2006) Marxism and social theory. New York: Palgrave Macmillan.

La República (2003) 'Wagner en desacuerdo con retiro del G-21', 10 October 2003.

La República (2004) 'TLC: Renuncia de funcionario revela fragilidad del Perú en negociaciones', 16 September 2004.

La República (2007) 'CTP a favor de TLC con Estados Unidos’, 6 August 2007.

Latimer, A. (2012) 'States of Sovereignty and Regional Integration in the Andes'. Latin American Perspectives. 39(1): 78-95.

Levitsky, S. and Mainwaring, S. (2006) 'Organized Labor and Democracy in Latin America'. Comparative Politics. 39(1), 21-42.

Lipietz, A. (1984) 'Imperialism or the Beast of the Apocalypse'. Capital \& Class. 84(1): 81-109.

McClintock, C. and Walls, F. (2003) The United States and Peru. Cooperation at a cost. New York: Routledge.

Mendoza Nava, A. (2009) Las Cartas sobre la Mesa. Similitudes y diferencias entre los compromisos del TLC con los Estados Unidos y del Acuerdo Comercial con la Unión Europea. Lima: RedGE.

MINCETUR (2005a) TLC Perú-Estados Unidos: Nociones Claves. Lima: MINCETUR.

MINCETUR (2005b) TLC y el Agro: Todo lo que el productor y el trabajador agrario deben saber sobre el TLC. Lima: MINCETUR.

MINCETUR (2005c) Análisis del Impacto del Tratado de Libre Comercio Perú-EEUU. Lima: MINCETUR.

Morton, A.D. (2007) Unravelling Gramsci: Hegemony and Passive Revolution in the Global Political Economy. London: Pluto Press. 
Mujica Petit, J. (2009) Cuando el comercio avanza y el trabajo decente retrocede. Análisis de los decretos legislativos en el TLC Perú-EE.UU. en materia laboral. Lima: RedGE.

PLADES (2007) Derechos laborales y comercio en América Latina: Análisis de las cláusulas laborales en el TLC con EE.UU. y en los acuerdos comerciales con la Unión Europea. Lima: PLADES.

Poulantzas, N. (1978) State, power, socialism. London: New Left Books.

RedGE (2010) 'Implementation of the FTA broadens and perpetuates the precariousness of labour, imposing a new labour regime: Law on Medium and Small Companies (SME)'. RedGE Policy Brief, [Online] Available at http://redge.org.pe/sites/default/files/200809\%20Alerta \%20Informativa\%20MYPE\%20ingles.pdf [Accessed: 13 January 2014].

RedGE (2012) 'Agroexportación y trabajo decente. Urgen reformas para redistribuir los beneficios del boom agroexportador a las y los trabajadores'. Alerta Urgente Policy Brief No. 9, [Online] Available at http://redge.org.pe/sites/default/files/alerta_urgente_9_derechos \%20laborales\%20FINAL.pdf [Accessed: 13 January 2014].

Roberts, K.M. (1998) Deepening Democracy? The Modern Left and Social Movements in Chile and Peru. Stanford: Stanford University Press.

Ruiz Caro, A. (2006) Riesgos del TLC Perú-EEUU. Oxfam International.

Solfrini, G. (2001) 'Populism and Authoritarianism in Peru: An Old Vice and the Neoliberal Era', in J. Demmers, A.E. Fernández Jilbeirto and B. Hogenboom (Eds.) Miraculous Miracles: The Neoliberalization of Latin American Populism. London: Zed Books, pp. 108-131.

Solidarity Center (2009) Peruvian Society, Workers, and Labor Law. December 2009, [Online] Available at http://www.solidaritycenter.org/files/policybrief_peru.pdf [Accessed: 13 January 2014].

SOMO (2011a) Gender aspects in the Latin American garment industry. SOMO Paper, April 2011. Amsterdam: SOMO.

SOMO (2011b) Bitter Fruit. Socio-economic issues in fresh fruit and vegetables supply chains of Dutch supermarkets - the case of Ahold. SOMO Paper, January 2011. Amsterdam: SOMO.

Tanaka, M. (2005) Democracia sin partidos Perú, 2000-2005. Los problemas de representación y las propuestas de reforma politcas. Lima: Instituto de Estudios Peruanos.

Teichman, J.A. (2001) The Politics of Freeing Markets in Latin America: Chile, Argentina and Mexico. Chapel Hill: University of North Carolina Press. 
Truth and Reconciliation Commisson (2003) Final Report, Available at http://cverdad.org.pe/ifinal/ [Accessed: 13 January 2014].

USTR (2007) Bipartisan Trade Deal, 10 May 2007, [Online] Available at http://www.ustr.gov/ sites/default/files/uploads/factsheets/2007/asset_upload_file127_11319.pdf [Accessed: 13 January 2014].

USTR (2013) US Generalized System of Preferences Guidebook. Washington: USTR.

Van Apeldoorn, B. (2002) Transnational capitalism and the struggle over Eureopan integration. New York: Routledge.

Van Apeldoorn, B. (2004) 'Theorizing the transnational: A historical materialist approach', Journal of International Relations and Development. 7(2): 142-176.

Van der Pijl, K. (1998) Transnational classes and international relations. London and New York: Routledge.

Wise, C. and Quiliconi, C. (2010) ‘ ¿Coalición de voluntades? El impulso estadounidense a los acuerdos de comercio bilateral con América Latina en la década de 2000', in J.R. Perales and E. Morón (Eds.) La Economía Política del Tratado de Libre Comercio entre Perú y Estados Unidos. Washington: Woodrow Wilson Center for International Scholars, pp. 25-41.

Wissen, M., and Brand, U. (2011) 'Approaching the Internationalisation of the State: An Introduction', Antipode. 43(1): 1-11.

Wood, E.M. (2005) Empire of Capital. London: Verso.

\section{BIOGRAPHICAL NOTE}

BART-JAAP VERBEEK is a PhD Candidate at the Department of Political Science of the Radboud University Nijmegen. His research deals with the political struggles that shape the content, form and scope of European bilateral and regional investment rules and practices in Latin America.

[email: j.verbeek@fm.ru.nl] 